\title{
Angka Kuman serta Upaya Pencegahan dan Pengendalian Infeksi di Ruang Operasi dan Ruang ICU Beberapa Rumah Sakit di Kota Bandar Lampung
}

\author{
Maria Tuntun, Marhamah \\ Jurusan Analis Kesehatan Politeknik Kesehatan Tanjungkarang
}

\begin{abstract}
Abstrak
Program Pencegahan dan Pengendalian Infeksi (PPI) di rumah sakit harus dijalankan untuk mencegah dan mengurangi kejadian infeksi pada setiap orang yang berada di rumah sakit. Tujuan penelitian untuk mengetahui angka kuman dan pelaksanaan pencegahan dan pengendalian infeksi (PPI) di ruang operasi dan ruang ICU beberapa rumah sakit di Kota Bandar Lampung. Jenis penelitian ini adalah studi kasus dengan pendekatan kualitatif. Pengambilan data dengan cara pemeriksaan angka kuman dan wawancara mendalam pada partisipan di ruang operasi dan ruang ICU rumah sakit. Hasil penelitian untuk angka kuman di ruang operasi, masih ditemukan melebihi standar yang seharusnya pada satu rumah sakit. Sedangkan angka kuman di ruang ICU sudah memenuhi standar. Hasil wawancara dengan partisipan di ruang operasi dan ICU menunjukkan bahwa di ketiga rumah sakit telah terbentuk Tim PPI, dengan tugas utamanya sebagai pengawasan dan monitoring pelaksanaan PPI. Sarana dan prasarana yang mendukung terlaksananya kegiatan ini telah tersedia dan mencukupi, seperti APD, sabun cuci tangan, hand rub, wastafel, air mengalir dan pelaksanaan sterilisasi alat-alat serta sterilisasi ruang operasi. Namun demikian kebiasaan mencuci tangan yang harus dilakukan oleh perawat sebelum dan setelah melakukan tindakan masih belum seratus persen, serta pengisian lembar surveilen belum diisi setiap hari.
\end{abstract}

Kata kunci : ruang operasi, ruang ICU, angka kuman, partisipan.

\section{Total of Bacteria and Efforts To Prevent and Control Infection in Operating Rooms and ICU in Several Hospitals in The City of Bandar Lampung}

\begin{abstract}
Infection Prevention and Control Programs (IPCP) in hospital must be implemented to prevent and reduce the incidence of infection in everyone who is in the hospital. The research objective was to determine the number of germs and the implementation of infection prevention and control in the operating room and ICU. This research is a case study with a qualitative approach. Retrieval of data by means of examination of germ numbers and indepth interviews with participants in the operating room and the ICU. The results of the study for the number of germs in the operating room, were still found to exceed the standards that should be in one hospital. Meanwhile, the number of germs in the ICU has met the standards. The results of interviews with participants indicated that in the three hospitals a IPCP Team had been formed, with the main task of being the supervision and monitoring of the implementation of the IPCP. Facilities and infrastructure that support the implementation of this activity are available and sufficient, such as PPE, hand soap, hand rub, sink, running water and the implementation of sterilization of tools and sterilization of operating rooms. However, the habit of washing hands that must be done by nurses before and after taking action is still not one hundred percent, and the survey sheet is not filled in every day.
\end{abstract}

Keywords : operating room, ICU, total of bacteria, participants. 
Korespondensi: Maria Tuntun Siregar, Jurusan Analis Kesehatan Politeknik Kesehatan Tanjungkarang, Jalan Soekarno-Hatta No. 1 Bandar Lampung, mobile 085279583168, e-mail maria_tuntun@poltekkes-tjk.ac.id 


\section{Pendahuluan}

Setiap fasilitas pelayanan kesehatan harus melaksanakan kegiatan Pencegahan dan Pengendalian Infeksi (PPI). PPI adalah suatu upaya untuk mencegah dan meminimalkan terjadinya infeksi pada pasien, petugas, pengunjung, dan masyarakat sekitar fasilitas pelayanan kesehatan (Permenkes RI, 2017).

Rumah sakit merupakan fasilitas pelayanan kesehatan yang sangat kompleks. Sebagai unit pelayanan medis, di rumah sakit terdapat beberapa unit atau ruang untuk menangani pasien, seperti ruang operasi dan ruang ICU. Di dalam ruangan tersebut terdapat berbagai macam peralatan medis dari yang sederhana hingga yang modern dan canggih. Peralatan medis di ruang operasi dan ruang ICU harus memenuhi standar dalam penggunaannya, seperti harus steril untuk alat-alat tertentu (Depkes, 2018a).

Kamar operasi merupakan suatu unit khusus di rumah sakit yang berfungsi sebagai tempat untuk melakukan tindakan pembedahan yang membutuhkan kondisi steril dan kondisi khusus lainnya. Pasien yang dioperasi umumnya dalam keadaan lemah. Demikian juga dengan ruang ICU, yang merupakan tempat perawatan pasien dengan kondisi yang menurun dan lemah, sehingga kondisi ruangan dan peralatan yang berada didalamnya harus memenuhi sanitasi yang baik. Bila sterilisasi dan sanitasinya tidak baik maka dapat terjadi kontaminasi, baik pada udara, peralatan, perlengkapan, manusia, dan air (Depkes RI, 2002). Kualitas udara ruang yang kurang baik, selain dapat menyebabkan Sick Building Syndrome, dapat juga menyebabkan infeksi nosokomial. Sekitar 10-20\% infeksi nosokomial dapat disebabkan kualitas udara ruang rumah sakit karena beberapa cara transmisi kuman penyebab infeksi dapat ditularkan melalui udara (Depkes, 2008a).

Masih tingginya angka kuman di ruang operasi ditunjukkan oleh penelitian Sulistyo (2017) di RSUD Tugurejo Semarang, yang mendapatkan rata-rata angka kuman udara ruang operasi sesudah sterilisasi sebesar 24 $\mathrm{cfu} / \mathrm{m}^{3}$. Hasil penelitian Wismana (2016) di RS Mata Undaan Surabaya juga mendapatkan angka kuman udara ruang operasi melebihi standar yang diperbolehkan. Hasil penelitian Yonarossa (2014) di ruang ICU Rumah Sakit Islam Sultan Agung mendapatkan angka kuman rata-rata $43 \mathrm{cfu} / \mathrm{m}^{3}$ (melebihi standar yaitu $\left.10 \mathrm{cfu} / \mathrm{m}^{3}\right)$

Keberadaan bakteri di ruang operasi dan
ICU dapat disumbangkan oleh perawat, pasien atau karena pelaksanaan sterilisasi ruangan yang belum efektif, sehingga bakteri tersebut dapat menjadi penyebab kejadian infeksi nosocomial (Wirtanen, 2012)

Beberapa penelitian yang mendapatkan hasil angka kuman melewati standar Permenkes tahun 2017 di ruang operasi dan ICU rumah sakit, menjadi satu indicator bahwa ruangan tersebut masih terkontaminasi oleh bakteri. Hal ini sejalan dengan penelitian Tuntun (2018), penelitian Londok (2015) dan penelitian Hidayat (2014) yang menemukan bakteri pathogen di ruang operasi dan ruang ICU rumah sakit. Menurut Taslim (2016) dari beberapa rumah sakit di Indonesia, bahwa bakteri terbanyak di ruang ICU adalah Pseudomonas aeruginosa dan Klebsiella pneumonia. Bakteri ini merupakan sumber infeksi nosocomial di rumah sakit

Di Bandar Lampung terdapat beberapa rumah sakit baik rumah sakit pemerintah maupun rumah sakit swasta, dengan jumlah pasien yang cukup banyak. BPJS telah melibatkan banyak rumah sakit swasta untuk menangani pasien, sehingga pasien tidak menumpuk di rumah sakit pemerintah. Meningkatnya jumlah pasien di rumah sakit khususnya rumah sakit tipe $\mathrm{C}$ disebabkan sistem rujukan BPJS yang berjenjang, mulai dari puskesmas lalu ke rumah sakit tipe $C$. Banyaknya pasien yang butuh penanganan operasi perlu mendapat perhatian khusus. Karena masih sering terjadi infeksi akibat operasi, hal ini dapat membahayakan dan merugikan kesehatan pasien (Pasquarella, 2004). Demikian juga dengan ruang ICU (Taslim, 2016; Londok, 2015), dapat menjadi sumber infeksi nosokomial bagi pasien yang dirawat diruangan tersebut.

Bila rumah sakit tidak melaksanakan PPI dengan baik maka dapat meningkatkan kasus infeksi nosokomial yang merugikan semua pihak dan menjadi penyumbang bakteri resisten terhadap antibiotik. Tujuan penelitian ini untuk mengetahui pelaksanaan pencegahan dan pengendalian infeksi (PPI) di ruang operasi dan ruang ICU, serta angka kuman pada ruang operasi dan ICU rumah sakit di Kota Bandar Lampung.

\section{Metode}

Jenis penelitian ini deskriptif, dengan pendekatan kualitatif dan analitik observasional. Pendekatan kualitatif dalam penelitian ini untuk memaparkan pelaksanaan 
pencegahan dan pengendalian infeksi di ruang operasi dan ruang ICU beberapa rumah sakit di Kota Bandar Lampung.

Penelitian dilakukan bulan Agustus Oktober 2019, di tiga rumah sakit yang ada di Kota Bandar Lampung, pada ruang operasi dan ruang ICU (RS I, RS II, RS III). Pengumpulan data dilakukan dengan memeriksa angka kuman (Soemarno, 2000; Jawet, 2014). Pemeriksaan laboratorium berupa angka kuman di ruang operasi dan ICU dilakukan di Laboratorium Bakteriologi Jurusan Analis Kesehatan Poltekkes Tanjungkarang. Data berupa hasil wawancara mendalam (Indepth Interview) menggunakan pedoman wawancara. Alat pengumpul data pada penelitian ini adalah peneliti sendiri (human instrument) dengan menggunakan alat perekam untuk merekam informasi yang disampaikan oleh partisipan. Partisipan dipilih secara purposive sampling, yaitu perawat dan petugas IPCLN (Infection Prevention and Control Link Nurse) yang bekerja di ruangan operasi dan ruang ICU serta petugas IPCN (Infection Prevention and Control Nurse) dan Ketua PPI (Pengendalian Penyakit Infeksi) di masing-masing rumah sakit.

Penelitian ini telah disetujui Ethical clearence dari Komisi Etik Penelitian Kesehatan Politeknik Kesehatan Tanjungkarang dengan nomor: 223/EA/KEPK/-TJK/VIII/2019 tanggal 9 Agustus 2019.

\section{Hasil}

Data hasil pemeriksaan bakteriologi meliputi angka kuman dari ruang operasi dan ruang ICU rumah sakit dapat dilihat pada tabel di bawah ini.

Tabel 1. Angka kuman dari ruang operasi dan ruang ICU

\begin{tabular}{lllc}
\hline \multirow{2}{*}{ No } & \multicolumn{1}{c}{ Ruang } & Sampel & $\begin{array}{c}\text { Angka Kuman } \\
\left(\mathbf{C F U} / \mathbf{m}^{3}\right)\end{array}$ \\
\cline { 2 - 4 } A & RS I & & \\
\hline 1 & Ruang ICU & Udara & 7 \\
\hline 2 & Ruang Operasi setelah digunakan & Udara & 7 \\
\hline 3 & Ruang Operasi setelah disterilisasi & Udara & 4 \\
\hline B & RS II & & \\
\hline 1 & Ruang ICU & Udara & 4 \\
\hline 2 & Ruang Operasi setelah digunakan & Udara & 8 \\
\hline 3 & Ruang Operasi setelah disterilisasi & Udara & 5 \\
\hline C & RS III & & 36 \\
\hline 1 & Ruang ICU & Udara & 22 \\
\hline 2 & Ruang Operasi setelah digunakan & Udara & 8 \\
\hline 3 & Ruang Operasi setelah disterilisasi & Udara & \\
\hline & & & \\
\hline
\end{tabular}

Pada tabel 1 angka kuman pada ruang operasi dan ICU RS I dan RS II memenuhi syarat, yaitu kurang dari $10 \mathrm{CFU}$ untuk ruang operasi dan kurang dari 200 CFU untuk ruang ICU. Tetapi pada RS III angka kuman di ruang operasi melebihi batas maksimal yag diperbolehkan, sedangkan angka kuman di ruang ICU memenuhi syarat yaitu kurang dari $200 \mathrm{CFU} / \mathrm{m}^{3}$.

Dalam penelitian ini telah dilakukan wawancara dengan partisipan dan IPCN yang bekerja di ruang operasi dan ruang ICU rumah sakit, serta IPCN dan Ketua PPI di masingmasing rumah sakit.

Secara umum informasi yang disampaikan IPCN tentang pembentukan Tim
PPI di rumah sakit adalah tuntutan akreditasi rumah sakit, artinya sebelum pelaksanaan akreditasi masing-masing rumah sakit belum mempunyai Tim PPI. Sekarang masing-masing rumah sakit telah mempunyai Tim PPI yang terdiri dari Ketua PPI (Pengendalian Penyakit Infeksi), IPCN (Infection Prevention and Control Nurse) dan IPCLN (Infection Prevention and Control Link Nurse) (Depkes 2008b; WHO, 2004).

Dalam Peraturan Menteri Kesehatan Republik Indonesia Nomor 27 Tahun 2017 Tentang Pencegahan dan Pengendalian Infeksi (PPI) di Fasilitas Pelayanan Kesehatan memuat tugas utama IPCN adalah memonitoring pelaksanaan program PPI, kepatuhan penerapan 
SPO dan memberikan saran perbaikan bila diperlukan, melaksanakan surveilans infeksi dan melaporkan kepada komite/tim PPI. Sedangkan tugas dari IPCLN adalah sebagai perawat pelaksana harian atau penghubung dengan IPCN, bertugas mengisi dan mengumpulkan formulir survei setiap pasien di unit tugasnya masing-masing (Depkes, 2018a; Depkes 2018b).

Dari ke tiga rumah sakit, petugas IPCN nya telah mengikuti pelatihan dasar dan lanjutan PPI, tetapi untuk petugas IPCLN baru mengikuti pelatihan yang diadakan oleh rumah sakitnya masing-masing. Di ruang operasi dan ruang ICU telah ada petugas IPCLN, yang merupakan ujung tombak monitoring pelaksanaan PPI di ruangan. Salah satu hambatan yang masih dirasakan oleh IPCLN dalam tugasnya adalah pengisian lembar surveilen yang harus diisi setiap hari, karena akan dilaporkan di akhir bulan kepada IPCN. Seperti yang dikatakan oleh salah satu IPCLN:

....kadang-kadang tidak sempat mengisi lembar surveilen, karena banyaknya pekerjaan, sehingga baru dapat mengisi keesokan harinya, atau perawat yang jaga lupa mengisi lembar surveilen ......

Demikian juga dengan IPCN, masih mengalami hambatan karena banyaknya tugas yang harus dikerjakan, sehingga tidak bisa memonitor ruangan setiap hari, kecuali jika ada kasus yang penting, ini informasinya:

...kami sebagai petugas IPCN harus berkeliling setiap hari ke ruangan untuk melihat pelaksanaan PPI di ruangan, tetapi jika sedang ada tugas tambahan maka baru dapat memonitor ruangan setelah beberapa hari, atau seminggu kemudian ...

Untuk sarana dan prasarana yang menunjang PPI, khususnya di ruang operasi dan ICU di ketiga rumah sakit telah memadai, seperti sabun cuci tangan (hand wash dan hand rub), wastafel, alat pelindung diri (masker, sarung tangan, kacamata, apron). Tetapi ada sedikit masalah dengan sabun cuci tangan yang disediakan pihak rumah sakit, karena baunya kurang enak dan membuat kulit tangan menjadi kering. Hal ini disampaikan oleh partisipan dari ruang operasi salah satu rumah sakit, yaitu:

...kita kan harus cuci tangan sebelum dan setelah melakukan tindakan, atau sebelum dan setelah memegang pasien, nah karena seringnya cuci tangan, tangan ini kulitnya terasa seperti kering. Dan bau sabunnya itu kurang enak, dan setelah kami sampaikan ke petugas IPCN, akhirnya sabun cuci tangannya diganti...
Hasil penelitian ini tidak sejalan dengan penelitian Sapardi (2018) di rumah sakit Ibnu Sina Padang, yang mendapatkan sarana dan prasarana PPI belum memenuhi kebutuhan yang seharusnya, seperti kurangnya handrub disetiap ruangan, dan masih ada wastafel yang tidak berfungsi.

Kegiatan sterilisasi ruang operasi, berbeda beda di ketiga rumah sakit tersebut, pada RS I dilakukan bongkaran besar dan sterilisasi dengan cara foging setiap hari sabtu, di RS II sterilisasi dilakukan dengan sinar UV di hari sabtu setiap minggu, sedangkan di RS III sterilisasi dengan cara melap menggunakan bahan kimia tertentu pada alat-alat yang ada di ruang operasi termasuk dinding, dan lantai. Tetapi ketiga rumah sakit mempunyai cara yang sama untuk membersihkan alat-alat yang ada setelah selesai operasi, seperti yang disampaikan oleh partisipan RS II:

...kalau sudah selesai operasi, semua alatalat dibersihkan dengan cara dilap menggunakan bahan kimia tertentu. Alat-alat operasi seperti gunting, pisau dan lain lain dibersihkan, lalu dimasukan dalam kantung untuk di bawa ke ruangan sterilisasi. Kami menjaga jangan sampai terjadi infeksi nosokomial dari ruang operasi ini. Tetapi kalau sedang banyak operasi, kadang-kadang tidak sempat membersihkan secara maksimal, karena harus melakukan tindakan operasi lagi ...

Secara umum infeksi nosokomial pernah terjadi di ketiga rumah sakit, tetapi sangat jarang dan sedikit. Jika terjadi infeksi nosokomial maka dilaporkan kepada IPCN untuk segera ditangani dan ditindak lanjuti. Partisipan dari RS III menyampaikan:

...waktu sedang pembangunan gedung di sebelah, maka banyak debu yang masuk ke ruang operasi. Dan ada beberapa ruang terbuka di ruangan operasi, maka pernah terjadi kasus infeksi luka operasi. Tetapi setelah ruang terbuka nya ditutup, tidak ada lagi kasus infeksi luka operasi ....

\section{Pembahasan}

Penelitian ini dilaksanakan di tiga rumah sakit yang ada di Kota Bandar Lampung, dengan melibatkan partisipan sebanyak 15 orang. Partisipan tersebut adalah ketua PPI, petugas IPCN, kepala ruangan dan staf perawat ruangan yang sekaligus sebagai IPCLN. Ke tiga rumah sakit tersebut yaitu RS I, RS II dan RS III telah terakreditasi dan mempunyai Tim PPI yang aktif. 
Hasil wawancara dengan partisipan di RS I, diketahui bahwa pasien di ruang ICU tidak selalu ada setiap harinya, karena pasien sering langsung dirujuk ke rumah sakit tipe B. Sedikitnya pasien yang dirawat di ruang ICU, sejalan dengan hasil pemeriksaan angka kuman yang indeks $7 \mathrm{CFU} / \mathrm{m}^{3}$, tidak melebihi standar Permenkes RI nomor 7 tahun 2019 tentang Kesehatan lingkungan Rumah Sakit, yaitu kurang dari $200 \mathrm{CFU} / \mathrm{m}^{3}$.

Demikian juga dengan ruang operasi di RS I, hasil pemeriksaan angka kuman nya tidak melebihi standar Permenkes RI nomor 7 tahun 2019. Walaupun angka kuman memenuhi syarat Permenkes, hal ini tetap menjadi perhatian dalam melakukan sterilisasi pada ruangan tersebut perlu dievaluasi. Hal ini sejalan dengan yang disampaikan partisipan dari ruang operasi RS I, bahwa:

...jika banyak tindakan operasi dalam satu hari, maka sering tidak sempat membersihkan alat-alat dan tempat tidur pasien dengan baik. Hal ini disebabkan tenaga perawat di ruangan yang terbatas. Apalagi jika ada tindakan operasi sito, karena kami lebih megutamakan nyawa pasien ...

Untuk ruang operasi di RS I dilakukan bongkaran besar setiap hari sabtu, yaitu melakukan sterilisasi dengan cara foging, agar semua bagian bagian yang sulit dibersihkan terjangkau untuk dibersihkan. Bahan kimia yang berupa enzimatik diharapkan dapat membunuh semua mikroorganisma yang ada di ruangan operasi tersebut.

Bakteri yang terdapat di ruang operasi dan ICU dapat berasal dari petugas yang bekerja diruangan tersebut, yaitu jika petugas tidak menjalankan 5 momen cuci tangan, yaitu sebelum dan setelah melakukan tindakan, atau tidak menggunakan APD yang lengkap. Petugas PPI seperti IPCN dan IPCLN harus sering mengawasi dan memantau dokter, perawat/petugas kesehatan lainnya yang berada di ruangan tersebut untuk melaksanakan pointpoint penting dalam kegiatan PPI untuk menekan angka infeksi nosokomial yang terjadi. Kejadian infeksi nosokomial ini sangat merugikan, baik bagi pasien, petugas rumah sakit maupaun pengunjung.

Angka kuman di ruang operasi RS II masih memenuhi standar Permenkes RI nomor 7 tahun 2019, yaitu indeksnya 8 setelah digunakan dan 5 setelah disterilkan. Tetapi untuk ruang operasi RS III, angka kumannya melebihi standar Permenkes RI nomor 7 tahun 2019. Hal ini dapat disebabkan cara sterilisasi ruang operasi di RS III yang hanya melap alat- alat, tempat tidur, dan dinding di ruang operasi, tidak melakukan cara dengan sinar UV atau foging. Hal ini seperti yang disampaikan partisipan dari ruang operasi RS III:

...setiap pagi kami melap alat-alat, meja, dan tempat tidur yang ada di ruang operasi, lalu setelah selesai tindakan operasi kami melap kembali alat-alat, meja, dan tempat tidur operasi. Dalam satu hari kami dapat melakukan operasi dalam jumlah banyak, sementara tenaga kami terbatas...

Jumlah angka kuman pada ruang operasi salah satu rumah sakit dalam penelitian ini melebihi standar Permenkes tahun 2017, ternyata hal ini sama seperti yang didapatkan oleh penelitian Manap (2016) pada rumah sakit tipe A di Jakarta yang mendapatkan angka kuman diatas standar yang diharuskan. Bahkan Wirtanen (2012) mendapatkan adanya koloni bakteri yang tumbuh rata-rata 50-60 CFU / 20 $\mathrm{cm}$ pada permukaan alat-alat yang ada di ruang operasi.

Angka kuman yang tinggi di ruangan operasi ini sangat membahayakan bagi pasien yang menjalani operasi, karena dapat menyebabkan luka pasca operasi (CDC, 2016; Ducel, 2002; Darmadi, 2008). Jumlah angka kuman yang berada diatas standar, harus menjadi kehati-hatian bagi pemangku PPI di rumah sakit, karena dapat menunjukkan jumlah bakteri yang banyak. Bakteri ini yang dapat menyebabkan infeksi nosocomial.Penelitian Tuntun (2018) mendapati bakteri patogen yang telah resisten di ruang ICU salah satu rumah sakit tipe A di Bandar Lampung, dengan tingkat resisten mencapai $14,29 \%$ sampai $76,19 \%$. Secara prinsip, kejadian infeksi nosokomial dapat dicegah bila fasilitas pelayanan kesehatan secara konsisten melaksanakan program pencegahan dan pengendalian infeksi (PPI). Upaya ini bertujuan untuk memastikan perlindungan kepada setiap orang terhadap kemungkinan tertular infeksi dari sumber masyarakat umum dan disaat menerima pelayanan kesehatan pada berbagai fasilitas kesehatan (Permenkes, 2017).

Hambatan dalam pelaksanaan PPI ini diantaranya adalah masalah pemisahan sampah, cuci tangan atau penggunaan sarung tangan, hal ini disampaikan oleh partisipan dari ruang ICU RS II:

...teman-teman perawat masih ada yang membuang sampah infeksius ke dalam wadah sampah organik, ketika ditegur baru menyadari kesalahannya. Selain itu ada juga teman-teman perawat yang karena terburu-buru tidak menggunakan sarung tangan saat memegang 
pasien, atau tidak sempat cuci tangan karena pasien dalam keadaan gawat...

Kebiasaan membuang limbah medis belum pada tempatnya, ini sejalan dengan penelitian Rismayanti (2019), yaitu masih ada sampah infeksius yang dibuang kedalam wadah sampah non infeksius. Hal ini akan menyebabkan limbah infeksius mengkontaminasi limbah non infeksius yang penanganannya berbeda.

Budaya cuci tangan perlu digalakkan, agar tidak menularkan penyakit dari satu orang ke orang lain. Tangan merupakan media yang baik untuk pertumbuhan bakteri, dan dapat memindahkan bakteri ke orang lain, sehingga dapat menyebabkan infeksi nosocomial (Septiari, 2012). Pihak rumah sakit harus terus memperbaiki sistem pelaksanaan PPI, agar tidak merugikan semua pihak yang terlibat.

Secara umum hasil observasi peneliti di ke tiga rumah sakit tersebut, mendapatkan telah banyak upaya Tim PPI memasang gambargambar sebagai informasi pencegahan dan pengendalian penyakit infeksi, seperti gambargambar mengenai cara batuk yang benar, penyediaan tempat sampah, wastafel dengan air mengalir serta sabun cuci tangan atau hand rub.

Simpulan dalam penelitian ini (1) angka kuman pada semua ruang ICU dalam penelitian ini tidak melebihi standar Permenkes RI nomor 7 tahun 2019, tetapi ada satu ruang operasi yang hasil pemeriksaan angka kuman melebihi batas standar (22 $\left.\mathrm{CFU} / \mathrm{m}^{3}\right)$. (2) Pelaksanaan pencegahan dan pengendalian infeksi di ruang operasi dan ruang ICU ke tiga rumah sakit (RS I, RS II, RS III) telah dilaksanakan, seperti telah ada Tim PPI yang terdiri dari petugas IPCN dan IPCLN. Penggunaan APD, cuci tangan serta tindakan aseptik, sterilisasi alat-alat dan sterilisasi ruangan operasi telah dijalankan.

Saran yang dapat disampaikan, yaitu: (1) Rumah sakit harus mengutamakan pencegahan dan pengendalian infeksi, dengan menjalankan aturan-aturan dalam PPI. (2) Semua petugas PPI (IPCN, IPCLN) harus mendapatkan pendidikan dan pelatihan dasar tentang PPI, serta semua petugas kesehatan yang bekerja di rumah sakit harus mendapatkan pendidikan dan pelatihan dasar tentang PPI. (3) Harus dilakukan surveilen terhadap angka kuman dan spesies bakteri di ruang operasi dan ICU, serta ruang perawatan lainnya, untuk mengetahui kemampuan dari sterilisasi yang dilakukan pada ruang tersebut.

\section{Daftar Pustaka}

CDC. 2016. National and state healthcareassociated infections 2016. Progress report. Available at www.cdc.gov/hai/ progress-report/index.html.

Darmadi, 2008. Infeksi Nosokomial Problematika Dan Pengendaliannya, Salemba Medika, Jakarta

Depkes RI. 2002. Keputusan Menkes RI No. 228/MENKES/SK/III/2002 tentang Pedoman

Penyusunan Standar Pelayanan Minimal Rumah Sakit yang Wajib Dilaksanakan Daerah.

Departemen Kesehatan RI. 2008a. Pedoman Pencegahan Dan Pengendalian Infeksi Di

Rumah Sakit Dan Fasilitas Pelayanan Kesehatan Lainnya. Dirjen Pelayanan Medik. Jakarta.

Departemen Kesehatan RI, Perdalin, RSRI Sulianti Saroso. 2008b. Pedoman manajerial

pencegahan dan pengendalian infeksi di rumah sakit Dan Fasilitas Pelayanan Kesehatan Lainnya. Dirjen Bina Pelayanan Medik. Jakarta.

Ducel G, Fabry J, Nicolle L 2002. Epidemiology Of Nosocomial Infections.. Dalam Prevention Of Hospitalacquired Infections, A Practical Guide. Edisi Ke-2. Malta : World Health Organization; 2002. H. 4-8. [Disitasi 21 Januari 2017]. Tersedia Dari : Www.Who.Int/Csr/Resources/Publicatio ns/Drugresist/En/ Whocdscsreph 200212.Pdf.

Hidayat, Eka S. 2014. Identifikasi Pola Kuman Pada Ruang Intensive Care Unit (Icu) Di

Rsud Dr. H. Abdul Moeloek Bandar Lampung. Jurnal Kedokteran Dan Kesehatan, 2014 (1) 1

Jawetz E., Melnick J.L., Adelberg E.A. 2014. Bakteriologi Kedokteran. EGC Press. Jakarta.

Londok, PV, Heriyannis Homenta, Velma Buntuan.Pola Bakteri Aerob Yang Berpotensi Menyebabkan Infeksi Nosokomial Di Ruang ICU BLU RSUP Prof. Dr. R. D. Kandou Manado Jurnal 
e-Biomedik (eBm), 2015:(3)1, JanuariApril

Manap, UR. 2016. Gambaran sanitasi lingkungan rumah sakit berdasarkan parameter fisik dan biologi pada 2 rumah sakit tipe A di Jakarta tahun 2016. Skripsi. UIN Syarif Haiyahtullah. Jakarta.

Pasquarella, C. Poletti, Pizura dkk. 2004. Guidelines for environmental infection control in health-care facilities. Recommendations of CDC and the Healthcare Infection Control Practices Advisory Committee (HICPAC). MMWR. Recommendations and reports : Morbidity and mortality weekly report. Recommendations and reports / Centers for Disease Control

Peraturan Menteri Kesehatan Republik Indonesia Nomor 27 Tahun 2017 Tentang Pencegahan dan Pengendalian Infeksi (PPI) di Fasilitas Pelayanan Kesehatan

Rismayanti, M. Hardisman. 2019. Gambaran Pelaksanaan Program Pencegahan dan Pengendalian Infeksi Di Rumah Sakit Umum X Kota Y. Jurnal Kesehatan Andalas 2019; 8(1)

Sapardi, VS. Rizanda M, Reni prima G. 2018. Analisis Pelaksanaan Manajemen Pencegahan Dan Pengendalian Healthcare Associated Infections Di RSI Ibnusina. Jurnal Endurance 3(2) Juni 2018 (358-366)

Septiari. (2012). Infeksi Nosokomial. Yogyakarta Nuhu Medika.

Soemarno. 2000. Isolasi Dan Identifikasi Bakteri Klinik. Edisi Ketiga. Akademi Analisis Kesehatan Yogyakarta. Departemen Kesehatan Republik Indonesia. Yogyakarta.
Sulistiyo, AD., Suhartono, Dharminto. 2017. Studi Tentang Angka Kuman Udara Di Ruang Operasi Rsud Tugurejo Semarang. Jurnal Kesehatan Masyarakat (E-Journal) Volume 5, Nomor 5, Oktober 2017. $\mathrm{h}$ ttp://Ejournal3.Undip.Ac.Id/Index.Php/J $\mathrm{km}$

Taslim, E., Tinni T. Maskoen Pola Kuman Terbanyak Sebagai Agen Penyebab Infeksi di Intensive Care Unit pada Beberapa Rumah Sakit di Indonesia. Anesthesia \& Critical Care. Vol. 34 No. 1, Februari 2016

Tuntun, M., Misbahul Huda. 2018. Pola Resistensi Bakteri Patogen Pada Ruang Perawatan dan Ruang Operasi RSUD. dr.H. Abdul Moeloek Bandar Lampung. Laporan Penelitian Hibah 2018. Poltekkes Tanjungkarang

WHO, 2004. Prevention Of Hospital Acquired Infection, A Practical Guide, 2 Edition. Diakses $26 \quad$ Februari 2010. Http://Www.Who.Int/Reseach/En/Amc.

Wismana, WS. 2016. Gambaran Kualitas Bakteriologi Udara Kamar Operasi dan keluhan Kesehatan. Jurnal Kesehatan Lingkungan Vol. 8, No. 2 Juli 2016: 219-228

Wirtanen, G. Nurmi, Salme, Kalliohaka, Tapio. Mattila, Inga dkk. 2012. Surface and air cleanliness in operating theatre environments. European Journal of Parenteral \& Pharmaceutical Sciences 2012; 17(3)

Yonarossa, Mirza Mutia (2014) Pola Kuman Di Udara Ruang Intensive Care Unit (ICU) Rumah Sakit Islam Sultan Agung. Thesis, Fakultas Kedokteran Unissula. Diunduh Dari Http://Repository.Unissula.Ac.Id/2545/ 